\title{
マイクロサッカードの解析に基づく視覚的注意の定量的測定 の試み
}

\section{Quantitatively Measuring Visual Attention by Analyzing Microsaccades}

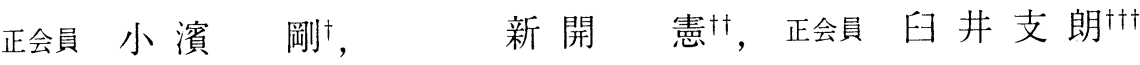

Takeshi Kohama ${ }^{\dagger}$, Ken Shinkai $^{\dagger \dagger}$ and Shiro Usui ${ }^{\dagger \dagger}$

\begin{abstract}
To evaluate the effects of visual attention (VA) on human involuntary miniature eye movements (MEM), we analyzed the microsaccades (MSC), which are components of MEM, under the following three experimental conditions: 1) VA was focused on the foveal object, 2) VA was dispersed in the parafoveal visual field, and 3) VA was focused on one of the parafoveal objects. The results showed that the VA was not focused on the foveal object, the frequency and amplitude of the MSC increased, and the scatter of fixation widened. The results from 2) and 3) showed that the frequency of the MSC was grater in 2) and the mean amplitude of the MSC was similar for both conditions. When VA is not focused, the MSC occur more frequently, and when VA is focused on the foveal object, the amplitude of the MSC reduces. These results suggest that MEM are influenced by VA, and MSC may be used as an indicator of the attentional state. It will be possible to establish whether VA is focused or not on the basis of the analysis of MEM characteristics.
\end{abstract}

キーワード : 眼球運動, 固視微動, マイクロサッカード, 視覚的注意, 定量的測定

\section{1. まえがき}

近年, 自動車運転中の電話利用時に生じる交通事故の増 加が社会問題化している。一般に，これらの事故の原因は 運転者が会話に注意を奪われたためであると考えられてい るようであるが，注意力のような精神活動をいかに扱うべ きかが問題となる。このことから, 注意の集中度に関する 定量的測定は重要な研究課題として位置づけられる.

一方, 一点を凝視する際に生じる固視微動は, 意識的に 制御できないことから，ノイズ的に生じる眼球運動と考え られてきた。しかしながら，テクスチャ観察時の眼球運動

1997 年 6 月 19 日, 映像情報メディア学会ヒューマンインフォメーション研 究会で発表.

1997 年 10 月 1 日受付, 1998 年 1 月 12 日再受付, 1998 年 2 月 9 日採録 †愛知県立大学 情報科学部

( $\bar{T}$ 480-1198 愛知県愛知郡長久手町大字熊張字茨ヶ迴間 1522-3, TEL 056164-1111)

†† NHK 山口放送局

（₹ 753-8660 山口県山口市中央 5-14-22, TEL 0839-21-3726)

††豊橋技術科学大学 情報工学系

（广 441-8580 愛知県豊橋市天伯町字雲雀分丘 1-1, TEL 0532-46-7806)

$\dagger$ Faculty of Information Science and Technology, Aichi Prefectural University

(1522-3, Aza-Ibaragabasama, Oaza-Kumabari, Nagakute-cho, Aichigun, Aichi 480-1101, Japan)

$\dagger \dagger$ NHK Yamaguchi

(5-14-22, Chuoh, Yamaguchi-shi, Yamaguchi 753-8660,Japan)

$\dagger \dagger \dagger$ Department of Information \& Computer Sciences, Toyohashi University of Technology

(1-1, Hibarigaoka, Tenpaku-cho, Toyohashi-shi, Aichi 441-8580, Japan)

映像情報メディア学会誌Vol. 52, No. 4, pp. 571〜576（1998）
を解析した報告1)によると，視覚刺激の構造や空間周波数 特性が固視微動に影響を及ぼすことが示唆されており，固 視微動上に高次脳機能が反映されている可能性は否定でき ない。

注視機構に関する生理学的知見によると, 注視時には,

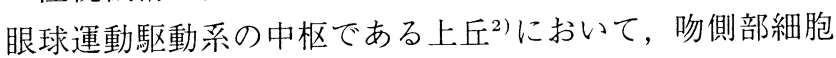
の活動により，その周辺の眼球運動誘起性の細胞を抑制し ているものと考えられている3(1) 。これらの上丘細胞は，視 覚的注意のコントロールに関係する頭頂連合野から興奮性 の入力を受けていることが知られており ${ }^{50)}$, 注視時に視覚 的注意をコントロールすることにより，上丘細胞の活動の 統制に乱れが生じ，これが固視微動の変動として現れるこ とが予想される。したがって, 固視微動の観測により, 注 視機構への視覚的注意の関与を推測できるものと思われる.

特に，固視微動の一成分であるマイクロサッカードは， 随意性の眼球運動であるサッカードと同じ制御系を有する ことが示されており7), サッカードが視覚的注意と密接に 関係していることを考慮すると息〜11)，マイクロサッカー ドに視覚的注意の影響が現れる可能性が高い.したがって， マイクロサッカードの解析に基ついた視覚的注意の定量的 観測手法の確立が期待される.

そこで本研究では, 固視微動を完全なノイズ様の眼球運 動とは見なさず，間接的に高次脳機能の制御下にあるもの と仮定し，注視を維持した状態で視覚的注意をコントロー 
ルする実験課題に対して, マイクロサッカードの発生頻度 や振幅について解析した，その結果から，視覚的注意のよ うな測定の困難な複雑な脳内活動が, 不随意性の眼球運動 に及ほす影響について考察し, 固視微動の解析に基づく視 覚的注意の定量化の可能性について論じる。

\section{2. 実 験 方 法}

注視時に生じる固視微動上に, 視覚的注意がどのような 影響を及ぼしているのかを考察するためには，注視を維持 した状態で視覚的注意をコントロールする必要がある。

本研究では, 注視時の視覚的注意の状態を次の 3 つに分 類し, それぞれの状態を作り出すような実験課題を提案す る. 各条件間でマイクロサッカードについて解析を行い, これらの比較検討を行う。

（1）視覚的注意が注視点近傍に集中している状態

（2）視覚的注意が周辺視野に分散されている状態

（3）視覚的注意が周辺視野の 1 部分に集中している 状態

2.1 実験課題 FT (Foveal Task)：視覚的注意が注 視点近傍に集中している状態

各実験課題では, 刺激呈示用ディスプレイの中央とその 上下左右に $3 \mathrm{deg}$ 離れた位置に 4 つ, 合計 5 つの円形視標 （直径 $0.2 \mathrm{deg}$ ）を呈示し, 次に記す FT, PT, CPTの 3 つの条件のうちのいずれかの条件において, 中央の視標へ の注視を維持した状態で, 5 つの視標の内のいずれか 1 つ に生じる色変化 (緑 $\rightarrow$ 黄緑) の有無を検出する. 被験者に は，実験の各セッションの開始前にどの条件で実験を行う かをあらかじめ教示した。

実験課題 FT では, 図 1 (a) 中の中央の視標に生じる 色変化を検出する。試行中は中央の視標を注視し続けなけ ればならない。

各試行は被験者がマウスをクリックすることにより開始

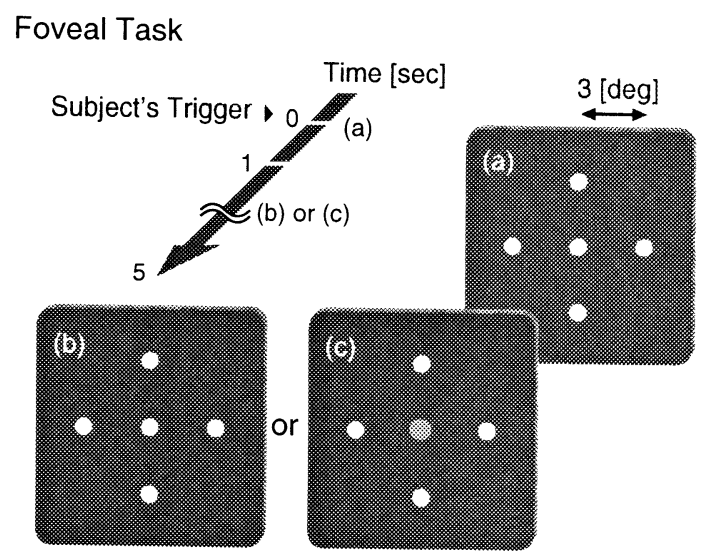

図 1 実験課題FT のタイムスケジュール

Schedule of Foveal Task (FT). Each trial began with a subject's trigger. After a $1 \sim 5$ second delay, the color of the central stimulus was changed at a rate of 50 percent. The subject was instructed to maintain fixation on the central stimulus during a trial.
される. 試行開始 1 秒後から 5 秒後までの適当な時間に， 中央の視標に $50 \%$ の確率で色变化が生じる，各試行の終了 後, ただちに回答セッションが開始され, 中央視標に色変 化が生じたか否かの回答が行われる。

視標の色の変化量は, 事前の予備実験結果から, 変化の 検出率が $80 \%$ 前後の值となるよう被験者ごとに調整した。 したがって，課題遂行のためには，被験者は試行中つねに 中央の視標に注意を集中しなければならない.

眼球運動の測定は, 強膜反射方式の測定装置（竹井機器, モデル 928）により，マウスクリックから 5 秒間，サンプ リング周波数 $500 \mathrm{~Hz}$ で計測される。各被験者に対し, 水 平・垂直方向について各々 $\pm 5 \mathrm{deg}$ の範囲で較正を行い, 12 ビットで量子化した。なお， 1 被験者に対して較正を行っ た後，紙で作成した義眼を用いてノイズの標準偏差を測定 した結果, 42 回の測定の平均は $0.057 \mathrm{deg}$ であった。

被験者は，日常生活において眼鏡を必要とせず，色覚異 常のない $22 \sim 24$ 歳の男性 4 人 (NY, KO, TU, NA) で あり，これまでに同様の実験への参加経験を有しないナ イーブな被験者である.

2.2 実験課題 PT (Parafoveal Task)：視覚的注意 が周辺視野に分散されている状態

実験課題 $\mathrm{PT}$ では, 周辺 4 視標のうちのいずれか 1 つに 生じる色変化の検出が課題として教示される。実験開始 1 秒後から 5 秒後までの間の適当な時間において，周辺 4 視 標からランダムに選択された 1 視標の色が $50 \%$ の確率で変 化する（図 2 ）。被験者には，どの視標に変化が生じるの かは知らされない. 視標の色の变化量は, 予備実験結果か ら各被験者ごとに $80 \%$ 程度の検出率となるよう調整した。 このとき, FT と同様に, 被験者は中央の視標を注視し続 けることが教示される。すなわち，注視を維持した状態で 周辺視野に呈示される 4 つの視標のうちのいずれかに生じ る色変化を検出しなければならない。したがって, 注視点 は中央の視標上にあるものの, 注意はその周辺に広く分散

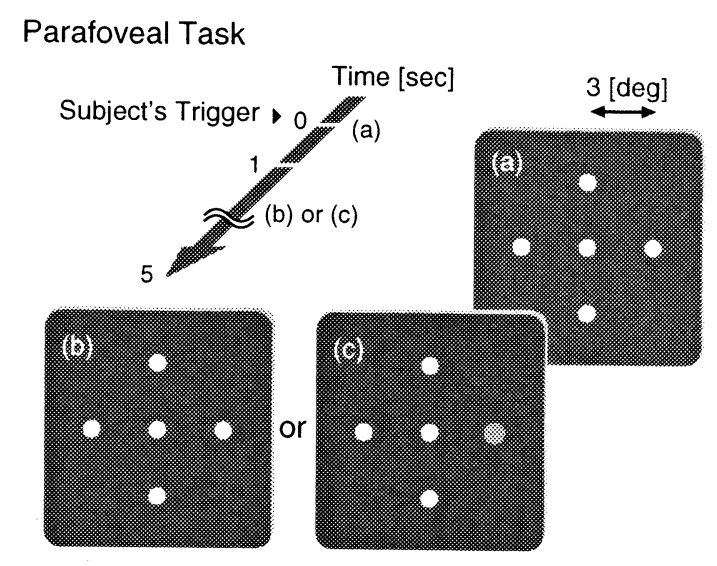

図 2 実験課題 PT のタイムスケジュール

Schedule of Parafoveal Task (PT). The procedure was the same as in "Fixation task", with an exception that the color of one of the peripheral stimuli, which was selected at random, was changed. 


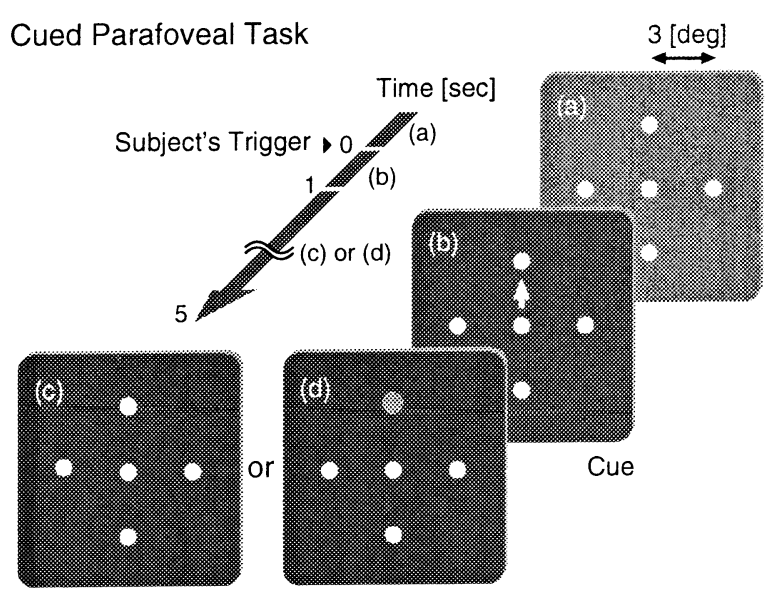

図 3 実験課題 CPT の夕イムスケジュール

Schedule of Cued Parafoveal Task (CPT). The procedure was different from "Parafoveal task" in following point. Just after the subject's trigger, an arrow was exposed for 1 second, then the color of peripheral stimuli indicated by an arrow was changed.

された状態にあると考えられる。その他の実験条件や被験 者についてはFT と同様である。

2.3 実験課題 CPT (Cued Parafoveal Task) : 視 覚的注意が周辺視野の 1 部分に集中している状態

実験課題 $\mathrm{CPT}$ では, 実験開始直後の 1 秒間, 矢印を呈 示することによって, あらかじめ色変化が生じる視標を被 験者に知らせておく. 矢印の長さは約 $0.3 \mathrm{deg}$ であり, 中 央視標から $1.5 \mathrm{deg}$ 離れた位置に呈示される. その他の実 験条件, 被験者, 視標の色の変化量の決定は, $\mathrm{PT}$ と共通 である(図 3)。したがって, 被験者は, 中央の視標上に 注視を維持したまま周辺視野のある一点に注意を集中する ことになる。

なお，眼筋の疲労による影響を排除するために，本実験 では 1 人の被験者に対して 1 日 42 試行に限定した。また, 実験課題に習熟するために各実験条件ごとに予め 100 試行 程度の練習を行った。

\section{3. 注視および有効試行の定義}

本研究で使用した眼球運動検出装置の測定原理である強 膜反射方式は, 一般に垂直方向の検出精度に問題があるこ とが知られている ${ }^{12)}$. そのため, 本研究では水平方向の眼 球運動のみを解析対象とした.

測定された眼球運動データの解析に際して, 1 試行中の注 視位置の変動が $1.5 \mathrm{deg}$ の範囲内にある場合を注視と定義 し，これを越える場合には試行中に中央視標の注視を維持 出来なかったものとしてて解析対象から除外した。 山田ら ${ }^{13)}$ は, 一般画像を観察する際の眼球運動について, $2 \operatorname{deg}$ 程 度の範囲内における滑らかな動きを注視と定義したが, 本 実験では注視用視標が呈示されていることから，これより も小さな範囲で注視を定義した。 なお, 有効試行数には被 験者および実験条件ごとに大きな偏りはなかった。

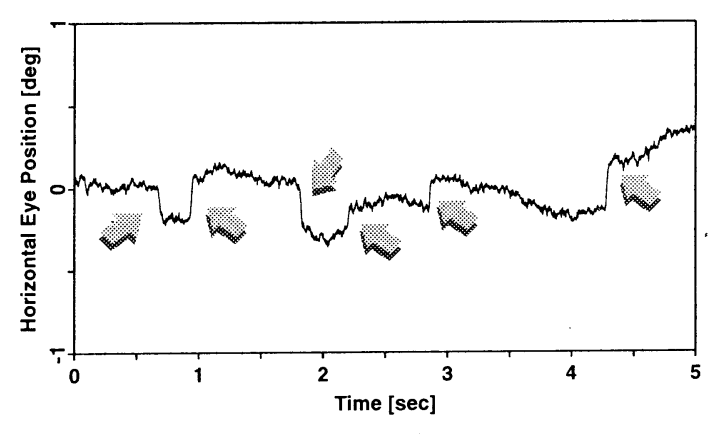

図 4 マイクロサッカードが検出された測定データの一例 An example of microsaccades in horizontal eye movement. The quick shifts indicated by arrows show the microsaccdes.

\section{4. 眼球運動データの平滑化}

固視微動のような微小な振幅の眼球運動を測定する場 合, 測定系ノイズの影響を無視できない。そこで, 本研究 ではウェーブレット変換を応用した平滑化手法によりノイ ズ除去を行った ${ }^{15)}$.この手法は, マイクロサッカードのよ うな微小なステップ状波形に対して，その位相を保持した まま測定系ノイズを有効に低減できることが示されている. ウェーブレット変換にあたっては, マザーウェーブレット

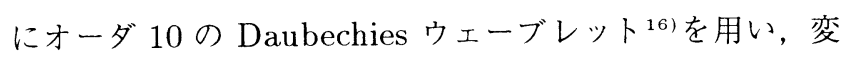
換後に高周波数に相当する上位 2 レベルを除いた逆変換に より平滑化波形を求めた。

\section{5. マイクロサッカードの検出方法}

図 4 に，実験条件 PT における水平方向の眼球運動波 形の 1 例を示す. 眼球位置は刺激呈示用ディスプレイの画 面中央を $0 \mathrm{deg}$ として表示してある. 検出されたマイクロ サッカードを矢印によって示す。

3章に記した注視の条件を満たすデータから, 眼球運動 の速度が $3.3 \mathrm{deg} / \mathrm{sec}$ の速度閾值を越えるものをマイクロ サッカードとして抽出した。図 5 (a) は $250 \mathrm{~ms}$ 間の眼球 運動波形例を, (b) は simple difference 型の低域微分フィ ル夕14)を用いて求められた速度波形を示している。速度䦨 值を越えた点から $10 \mathrm{~ms}$ 前をマイクロサッカードの開始 点とし, 再び速度閾值を下回った点から $10 \mathrm{~ms}$ 後をマイク ロサッカードの終了点として,この間の眼球の変位をマイ クロサッカードの振幅として定義した。これらの值は, 被 験者 2 人から得られた約 100 試行分の測定データから, パ ルス状波形のみを検出できる最適值として設定した。なお， 変位量が $0.06 \mathrm{deg}$ 未満の場合は微小なノイズとして解析 から除いた。

\section{6. 実験結果の解析}

\section{1 注視位置のばらつき}

まず，視覚的注意のコントロールにより，正確な注視の 維持にどのような影響が生じるかを考察するために, 注 
(a) Eye Movement

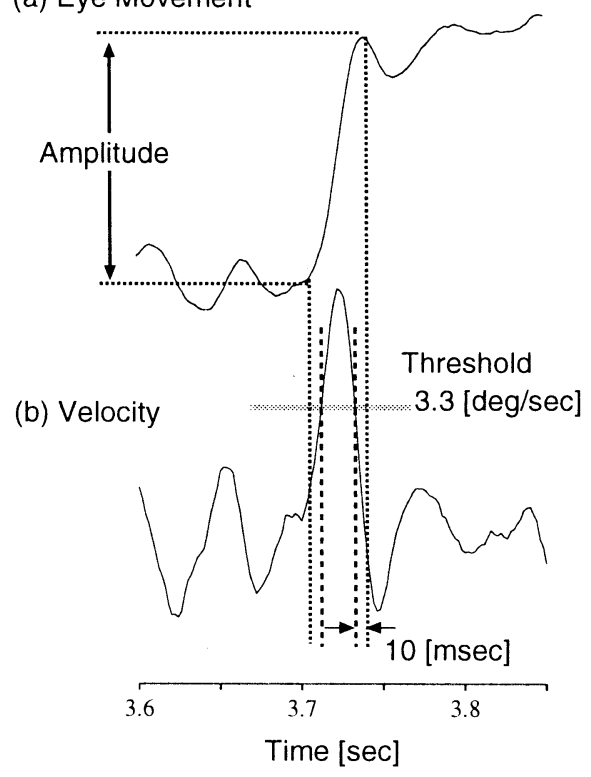

図 5 マイクロサッカードの検出方法と各パラメータの定義 Detection method of a microsaccade and definition of parameters for data analysis. (a) An example of eye movement for $250 \mathrm{~ms}$. (b) The velocity of exemplified eye movement. Microsaccades were detected when the velocity of eye movement exceeded the threshold $(3.3 \mathrm{deg} / \mathrm{sec})$. The amplitude of a microsaccade was defined as the difference between the presaccadic and postsaccadic eye positions.

視位置のばらつきについて各実験課題間での比較検討を 行った。

図 6 に注視位置の変位の平均值とその標準偏差を示す. 図中，例えば注視位置の平均值が負の值を示すものについ ては，その被験者が全試行を通じて注視用視標（中央の視 標）の左側を注視する傾向にあったことを示している。

すべての被験者に共通して，PT, CPTのそれぞれの 分散が FT の分散よりも有意に大きいことが示された $(P<0.01)$.このことから, 周辺視野に注意を分散し

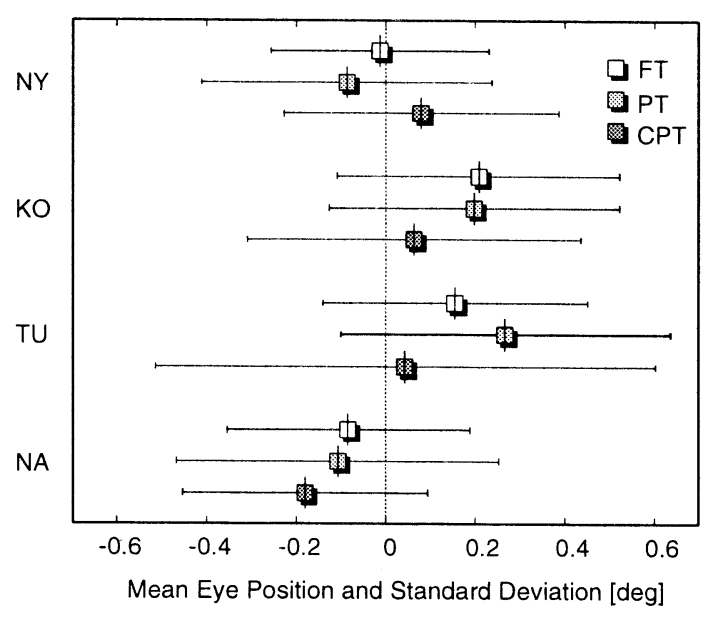

図 6 各実験条件における平均注視位置とその慓準偏差の比較 Mean value and standard deviation of the fluctuation of horizontal eye movements in each experimental condition.
た場合（PT）や，周辺のある一点に注意を集中した場合 （CPT）には，注視位置に注意を集中した場合（FT）に比 較して注視のばらつきが大きくなることが示唆される。す なわち，より正確に注視を維持するためには，注視点近傍 に注意を集中する必要があるものと考えられる。

一方，PTと CPT を比較した結果では，全被験者に共 通するような傾向は認められず，明確に区別できなかった。

注視時にはマイクロサッカードやドリフトなどのいわゆ る固視微動により，注視位置が $0.05 \sim 0.5 \mathrm{deg}$ 程度変動す ることが知られている ${ }^{17)}$. PT や CPT で注視位置のばら つきが大きくなった原因は, 視覚的注意のコントロールに より固視微動上になんらかの変化が生じている可能性が高 い.そこで, 固視微動のうちマイクロサッカードに注目し, マイクロサッカードの発生頻度と振幅の 2 点について視覚 的注意との関係について解析を行った。

\section{2 マイクロサッカードの発生頻度}

図 7に，1 試行あたりのマイクロサッカードの平均検出 数とその標準偏差を示す.

全ての被験者に共通して，PTでの平均検出数が $\mathrm{FT}$ の 場合よりも有意に大きい $(\mathrm{NY}, \mathrm{KO}, \mathrm{TU}: P<0.01$, $\mathrm{NA}: P<0.05)$ 。一方, FT と CPT を比較すると, NA を除く 3 人の被験者に共通して CPT の平均検出数の方が 大きいことから $(\mathrm{NY}, \mathrm{KO}: P<0.01), \mathrm{PT}$ ほど顕著で はないものの，マイクロサッカードの発生頻度が増加する 傾向にあるといえる。

また, $\mathrm{KO}$ を除く 3 人の被験者では, $\mathrm{CPT} の$ 平均検出数の 万が $\mathrm{PT}$ の場合よりも小さくなっている $(\mathrm{NY}: P<0.01)$. このことから, 視覚的注意が周辺視野の 1 部分に集中さ れた場合には，周辺視野に分散された場合と比較してマイ クロサッカードの発生頻度が低下する傾向にあると考えら れる。

以上の結果から，各実験条件間でのマイクロサッカード の発生頻度は, 概ね次のような関係にあることが示唆さ れる。

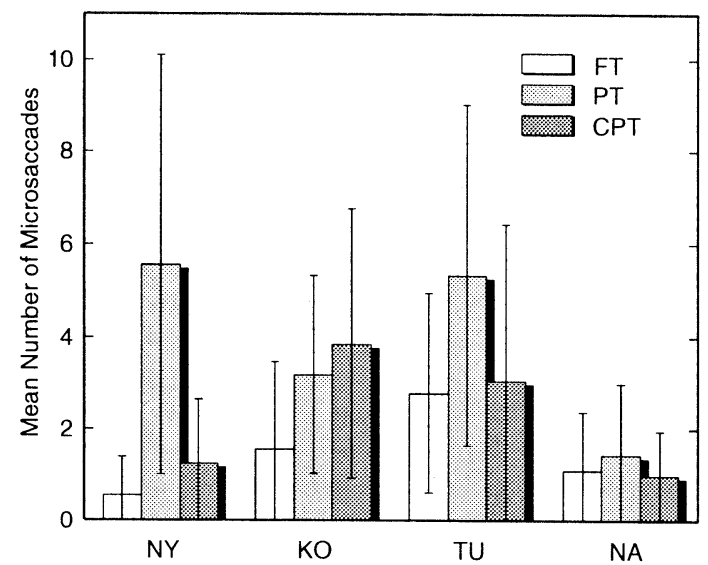

図 7 1 試行あたりのマイクロサッカード平均検出数の比較 Mean number and standard deviation of microsaccades per 1 trial for each experimental condition. 


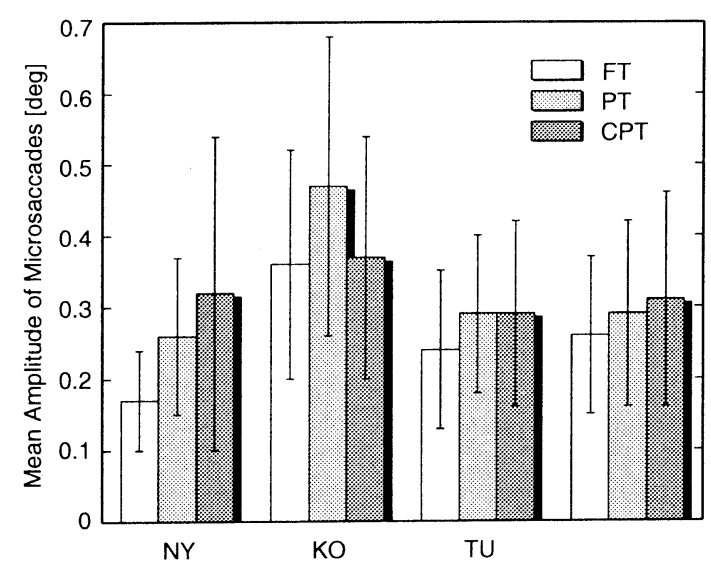

図 8 マイクロサッカード平均振幅の比較

Mean amplitude and standard deviation of microsaccades for each experimental condition.

\section{$F T<C P T<P T$}

すなわち，マイクロサッカードは，視覚的注意が固定さ れない場合に最も発生頻度が高くなり, 逆に注視点近傍に 集中された場合にその発生が抑えられると考えられる。 マ イクロサッカードの発生頻度の增減には, 視野内に注意が 集中されているか否かが関わっているものと推測される. したがって，マイクロサッカードの発生頻度の比較により， 視覚的注意の集中度合をある程度評価できるものと思わ れる。

\section{3 マイクロサッカードの振幅}

図 8に，検出されたマイクロサッカードの振幅平均值と 標準偏差を示す.

全被験者に共通して，FTよりも PT の方が平均振幅が大 きく $(\mathrm{NY}, \mathrm{KO}, \mathrm{TU}: P<0.01)$, 同様に, $\mathrm{FT}$ と $\mathrm{CPT}$ と の比較においても，CPT の方が平均振幅が大きくなって いる $(\mathrm{NY}, \mathrm{TU}: P<0.01)$ 。したがって, 注視点周辺へ の視覚的注意の分散により, マイクロサッカードの振幅が 大きくなる傾向にあるといえる。

一方，CPT と PT の間には，全被験者に共通するよう な一貫した傾向は認められない.

このことから，マイクロサッカードの振幅を比較するこ とにより, 視覚的注意が周辺視野に分散されているか, 周 辺視野の 1 部分に集中されていたかの違いを判断すること は困難であるものの, 視覚的注意が注視点近傍に集中され ているか否かを評価することは可能であると思われる。

\section{7. 考 察}

本実験で設けた 3 つの実験条件間での比較検討の結果, 視覚的注意が注視点近傍に集中された場合は, 注意が周辺 視野に分散された場合や，周辺視野のある 1 点に集中され た場合に比較して，注視位置のばらつきが小さくなること が示された。また，マイクロサッカードの発生頻度につい て比較した結果, マイクロサッカードの発生頻度は, 視覚 的注意が注視点近傍に集中された場合にもっとも小さく，
ついで視覚的注意が周辺視野のある一点に集中された場合， 視覚的注意が周辺視野に分散された場合の順で大きくなる ことが示された．さらに，マイクロサッカードの振幅につ いて解析した結果からは，マイクロサッカードの振幅は, 視覚的注意が注視点近傍に集中された場合にもっとも小さ くなることが示された。

これらの結果から，より正確な注視を維持するためには， 注視点近傍に注意を集中する必要があるものと推察され， マイクロサッカードの発生頻度や振幅を基準として, 視覚 的注意が注視点近傍に集中されているか否かの判断が可能 であることが示唆される。

追従運動と視覚的注意との関係を調べた報告によると ${ }^{18)}$, 注視を持続する際には，その背後で生じる事象に注意を向 けることが困難となり, 逆に, 背後の事象に注意を向ける と注視の維持が困難となることが示されている．この結果 から，注視を維持するためには，注視する対象に視覚的注 意を集中させる必要があると述べられており，本研究の結 果はこの見解を支持するものである.

実験条件間でマイクロサッカードに変化が生じた原因と して, 網膜上の錐体細胞の分布特性から, 周辺視野では錐 体細胞密度が小さくなるため ${ }^{19)}$ ，これによる感度の低下を 補うためにマイクロサッカードが発生していた可能性が考 えられる。本研究で使用した視覚刺激はすべての条件で 5 つの視標が同じ位置に呈示されていたため，もしこの仮定 が正しければ, 高次視覚系では対象となる刺激の位置を 判断した上で錐体細胞密度に応じてマイクロサッカードを 発生させていたことになる。しかしながら，マイクロサッ カードの発生後, 極めて短い間隔で次のサッカードが生じ ることから，マイクロサッカードは中枢から独立した眼球 運動であることが示されておりり ${ }^{20)}$ ，上の解釈に矛盾する。

生理学的知見によると，上丘には，それぞれが特定のサッ カードの方向と大きさをコーディングしている細胞と21) (ここでは，これをサッカード細胞と呼ぶ），固視時にの みサッカード細胞を抑制する吻側部の固視細胞（fixation cell）が存在しており ${ }^{3 / 4)}$. 両者が互いに抑制的に結合して いることが示唆されている31. 一方, サッカード発生時に は, その直前に視覚的注意の移動が生じることから ${ }^{81-11)}$, 視覚的注意の移動がサッカードのプログラミングプロセス に相当すると考えられる，さらに，上丘サッカード細胞に 電気刺激を与えることにより生じるサッカードは，視覚的 注意によってその方向に変化が生じることや ${ }^{22)}$, 視覚的注 意の空間的配置をコントロールしていると考えられている 頭頂連合野 ${ }^{23)}$ が上丘と強く結合していること吕などを考慮 すると，上丘でコーディングされるサッカード命令に視覚 的注意が関与している可能性が高い.

マイクロサッカードは，随意性のサッカード眼球運動と 同一の制御系により駆動されていることから7)，マイクロ サッカードの生成にも上丘が関係しており，視覚的注意の 影響下にあることが予想される。このことから，注視時に 
視覚的注意を分散させることにより,(1) 頭頂連合野から固 視細胞への抑制性の入力があり, 固視細胞によるサッカー ド細胞の抑制が弱まった，（2）頭頂連合野からサッカード 細胞に興奮性の入力があり, サッカード細胞により固視細 胞が抑制を受けた，などの原因によって，固視細胞とサッ カード細胞の活動が均衡状態となり, 注視の統制に乱れが 生じたものと推察される.

\section{8. むす び}

本研究では, 不随意な眼球運動である固視微動の解析に 基づいて, 視覚的注意の定量的観測が可能であるか否かを 確かめることを目的として，注視を維持した状態で視覚的 注意のコントロールを行う実験を考案し，このときの眼球 運動の解析を行った。

その結果, 随意性のサッカード眼球運動と同じ制御系を 有するマイクロサッカード上に視覚的注意の影響が見られ ることが示唆され, マイクロサッカードの特性を指標とし た視覚的注意の定量的測定の可能性が示された。

本研究により得られた知見は, 固視微動を視覚的注意の 客観的評価量として位置付けるだけでなく, 固視微動の生 起メカニズムの解明にあたっても多くの示唆を与えるもの であるといえる。

今後の課題として, 固視微動の周波数成分の解析を行い, 視覚的注意がドリフトのような低周波成分に与える影響に ついて考察するとともに，視覚的注意のコントロールに問 題があることが知られている, 痴呆症や精神分裂症などの 高次脳機能障害 24 - 26) に対する眼球運動を利用した診断シ ステムへの応用の可能性についても検討する予定である。

本論文をまとめるにあたり，細部にわたり活発な御討論 を頂いた, NHK 大阪放送局技術部 山田光穗チーフエンジ 二ア, 豊橋技術科学大学情報工学系戸田尚宏助教授, 同大 計算機センター 神山斉己助手, 同大情報工学系 中内茂樹 助手に感謝致します。

\section{〔文献〕}

1）境野英朋, 鉄谷信二, 岸野文朗: “最大エントロピー法と高次モーメント 特徵量に基づく眼球連動パターンの時系列解析”, 信学論 (A)，J76-A 8, pp. 1027-1041 (1993)

2) Hikosaka, O. and Wurtz, R. H. : "Modification of saccadic eye movements by GABA-related substances. I. Effect of muscimol and bicuculine in monkey superior colliculus", J. Neurophysiol. , 53, 1, pp. 266-291 (1985)

3) Munoz, D. P. and Wurtz, R. H. : "Fixation cells in monkey superior colliculus I. Characteristics of cell discharge", J. Neurophysiol. , 70, 2, pp. 559-575 (1993)

4) Munoz, D. P. and Wurtz, R. H. : "Fixation cells in monkey superior colliculus II. Reversible activation and deactivation", J. Neurophysiol. , 70, 2, pp. 576-589 (1993)

5) Lynch, J. C. , Graybiel, A. M. and Lobeck, L. J. : "The differential projection of two cytoarchitectonic subregions of the inferior parietal lobule of macaque upon the deep layers of the superior colliculus.", J. Comp. Neurol. , 235, pp. 241-254 (1985)

6) Andersen, R. A. and Gnadt, J. W. : "Posterior parietal cortex", The neurobiology of saccadic eye movements (Eds. Wurtz \& Goldberg) , Elsevier, pp. 315-335 (1989)

7) Carpenter, R. H. S. : "Movements of the Eyes (2nd Edition Re- vised and Enlarged)", London : Pion. , pp.124-138 (1988)

8 ) Remington, R. W. : "Attention and saccadic eye movements", J. Exp. Psychol.:Human Perception and Performance, 6, 4, pp.726744 (1980)

9) Shepherd, M. , Findlay, J. M. and Hockey, R. J. : "The relationship between eye movements and spatial attention", Q. J. Exp. Psychol., 38A, pp.475-491 (1986)

10) Hoffman, J. E. and Subramaniam, B. : "The role of visual attention in saccadic eye movements", Perception \& Psychophysics, 57, 6, pp.787-795 (1995)

11) Deubel, H. and Schneider, W. X. : "Saccade target selection and object recognition : Evidence for a common attentional mechanism", Vision Res., 36, 12, pp. 1827-1837 (1996)

12）山田光穗：“最近の眼球運動の研究動问”, 信学技報, MBE95-132, pp 145-152 (1995)

13）山田光穗, 福田忠楌：“画像における注視点の定義と画像分析への応用”, 信学論, J69-D, 9, pp. 1335-1341 (1986)

14) Usui, S., Amidor, I. : "Digital low-pass differentiation for biological signal processing", IEEE Trans. Biomedical Engineering, BME-29, 10, pp.686-693 (1982)

15）吉松浩：“ウェーブレットを用いた注視時眼球運動の平滑化”,テレビ 誌, 50, 12, pp. 1903-1912 (1996)

16) 榊原 進 : 数理科学 ウェーブレットビギナーズガイド, 東京電㙨大学出 版局 (1995)

17) Yarbus, A. L. : "Eye Movement and Vision", Plenum Press. pp. 103-127 (1967)

18) Khurana, B. ahd Kowler, E. : "Shared attention control of smooth eye movement and perception", Vision Res. , 27, 9, pp. 1603-1618 (1987)

19) Sharp, P. F. and Philips, R., "Physiological Optics", The Perception of Visual Information (Eds. Hendee, W. R., Wells, P. N. T. ), Springer-Verlag, pp. 1-29 (1993)

20) Kingstone, A. and Reuter-lorentz, P. A. , "Are microsaccades responsible for the gap effect?", Perception \& Psychophysics, 57, 6, pp. 796-801 (1995)

21) Robinson, D. A. : "Eye movements evoked by collicular stimulation in the alert monkey", Vison Res., 12, pp. 1795-1808 (1972)

22) Kustov, A. A. and Robinson, D. L. : "Shared neural contral of attentional shifts and eye movements", Nature, 384, 7, pp. 74-77 (1996)

23) Posner, M. I. and Petersen, S. E. : "The attention system of the human brain", Ann. Rev. Neurosci., 13, pp. 25-42 (1990)

24 ) 藤井 充, 深津 亮, 小林幹穂, 高畑直彦, 山田光穗, 福田忠彦, 村上新治 : “Alzheimer 病の神経心理学的研究-vision analyzer による視覚認識 過程の検款”, 精神神経誌, 91, 10, pp. 760-769 (1989)

25 ) 魚森謙也：“アルツハイマー病患者の眼球運動と加齢効果”, 視覚の科 学, 14, 4, pp. 166-170 (1993)

26）松江克彦，一葉英明：“エクスプレスサッカードに現れる注意の異常一 精神分裂病の追従眼球運動障害に関連して-”, 神経進歩, 40, 3, pp. 485-495 (1996)

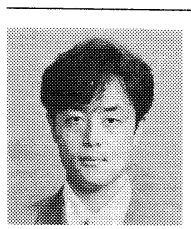

小濱剛 1992 年, 豊橋技術科学大学工学部知 識情報工学系卒業. 1997 年, 同大大学院博士後期課程 システム情報工学専攻修了. 現在, 愛知県立大学助手. 視覚系の情報処理過程における眼球運動の機能に関する 研究に従事. 江学博士. 正会員。

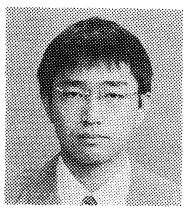

新開学 憲 1995 年, 豊橋技術科学大学丁学部情 報工学系卒業。1997 年, 同大大学院修士課程修了。現 在, NHK 山口放送局勤務. 在学中, 固視微動上に現わ 札る高次脳機能の研究に従事.

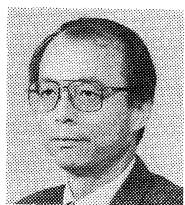

兒井 支朗 1974 年, カリフォルニア大大学院博 上課程. 電気工学計算機科学専攻修了. 同年, 名古屋大 学工学部助手。1 1979 年, 豊橋技術科学大学講師, 助教授 を経て，1986 年，教授。生体情報工学，生理丁学などの 研究に従事. 編著「脳・神経システムの数理モデル一視 覚系を中心に」，ほか. Ph.D. 正会員. 